\title{
EFFECT OF E-GLASS FIBER ADDITION ON MECHANICAL PROPERTIES OF HEAT-POLYMERIZED ACRYLIC RESIN DENTURE BASE
}

\author{
Sri Yuliharsini1, Ismet Danial Nasution², Harry Agusnar³, Putri Welda Utami Ritonga ${ }^{4}$
}

1 Postgraduate Program in Prosthodontics, Faculty of Dentistry, Universitas Sumatera Utara, Medan, Indonesia.

${ }^{2}$ Lecturer, Department of Prosthodontics, Faculty of Dentistry, Universitas Sumatera Utara, Medan, Indonesia.

${ }^{3}$ Lecturer, Department of Chemistry, Faculty of Mathematics and Natural Sciences, Universitas Sumatera Utara, Medan, Indonesia.

${ }^{4}$ Lecturer, Department of Prosthodontics, Faculty of Dentistry, Universitas Sumatera Utara, Medan, Indonesia.

\section{BACKGROUND}

ABSTRACT

Heat-polymerized acrylic resins are commonly used as denture base, but they have relatively low mechanical properties such as impact strength, transverse strength, and modulus of elasticity that made them susceptible to fracture during clinical applic ation. Various modifications were made to improve the mechanical properties of heat-polymerized acrylic resins, one of them was with the addition of E-glass fiber. We wanted to determine the effect of E-glass fiber (chopped strands of $3 \mathrm{~mm}$ size) with 1\% and 1.5\% weight concentration addition on mechanical properties (impact strength, transverse strength, and modulus of elasticity) of heatpolymerized acrylic resin denture base material and the correlation between them.

\section{MATERIALS AND METHODS}

Ninety samples of heat-polymerized acrylic resin were divided into 9 groups, consisting of impact strength, transverse strength and modulus of elasticity testing group. Each testing group consisting of group without and with addition of $1 \%$ and $1.5 \%$ E-glass fiber. Impact strength test was performed using Charpy impact tester, while transverse strength and modulus of elasticity were performed using the Universal Testing Machine. After the test, fracture surface of the samples was evaluated and scanning electron microscope view was taken. The effect of E-glass fiber addition to impact, transverse strength and modulus of elasticity on heatpolymerized acrylic resin was analysed with one-way ANOVA statistical test. Pearson Correlation test was then performed to determine the correlation between impact, transverse strength and modulus of elasticity.

\section{RESULTS}

There was an effect of E-glass fiber addition (chopped strands of $3 \mathrm{~mm}$ size) with $1 \%$ and 1.5\% weight concentration to impact strength $\mathrm{p}=0.0001(\mathrm{p}<0,05)$; transverse strength $\mathrm{p}=0,002(\mathrm{p}<0,05)$; and modulus of elasticity $\mathrm{p}=0.002(\mathrm{p}<0.05)$. Pearson Correlation test showed that there was no correlation between impact and transverse strength $(r=0.311$ and $p=0.094)(p>0.05)$; impact strength and modulus of elasticity $(r=0.284$ and $p=0.128)(p>0.05)$; and transverse strength with modulus of elasticity ( $r=-$ 0.044 and $\mathrm{p}=0.816)(\mathrm{p}>0.05)$.

\section{CONCLUSION}

Addition of $1 \%$ and $1.5 \%$ E-glass fiber can improve the impact strength, transverse strength, and modulus of elasticity of heatpolymerized acrylic resin denture base and the addition of $1 \%$ E-glass fiber can increase a balanced of impact strength, transverse strength, and modulus of elasticity of heat-polymerized acrylic resin denture base.

\section{KEYWORDS}

E-Glass Fiber, Heat-Polymerized Acrylic Resin Denture Base Materials, Mechanical Properties, Impact Strength, Transverse Strength, Modulus of Elasticity

HOW TO CITE THIS ARTICLE: Yuliharsini S, Nasution ID, Agusnar H, et al. Effect of E-glass fiber addition on mechanical properties of heat-polymerized acrylic resin denture base. J. Evolution Med. Dent. Sci. 2019;8(12):872-878, DOI: 10.14260/jemds/2019/194

\section{BACKGROUND}

A good denture should be able to meet the functional needs of the oral cavity and improve the quality of life in edentulous patients. Ideal denture base requirements include odourless; biocompatibility with oral tissue; high thermal conductivity; aesthetic; easy to manipulate and repair; high modulus of

'Financial or Other Competing Interest': None.

Submission 14-11-2018, Peer Review 12-03-2018,

Acceptance 19-03-2018, Published 25-03-2019.

Corresponding Author:

Dr Sri Yuliharsini

Jalan Alumni,

No. 2, Universitas Sumatera Utara,

Medan-20155, Indonesia,

E-mail: sriyuliharsini@yahoo.com

DOI: $10.14260 /$ jemds $/ 2019 / 194$

(c) $($ ) $९$ elasticity, impact strength, and transverse (flexural) strength; flexible and had strong adhesion strength with artificial teeth and lining materials. $1,2,3$

Based on ADA Specification No. 12 (ISO 1567), polymer denture base material is divided into five types. One of the most commonly used is type 1 heat-polymerizable polymers which are heat-polymerized acrylic resin processed with compression moulding method. ${ }^{1}$ The use of this material is very popular because it has several advantages such as light, biocompatible, aesthetic, relatively cheap, low water absorption, easy to manipulate, polish and repair,1,2,4,5 but this material is not yet ideal in fulfilling the mechanical requirements of a denture base because it has a relatively low impact strength, transverse strength, and modulus of elasticity, making it more susceptible to failure during clinical use. $3,5,6,7$

Denture fracture is a common clinical problem and important not only for patients but also for dentists and 
dental laboratory technicians. Fracture of the denture can be primarily due to the failure of impact, flexural or fatigue.3,8 Impact failure occurs due to a sudden collision on the denture or falls on a hard surface when cleaning the denture, coughing or sneezing.8,9 Flexural or fatigue failure occurs intraorally due to the continuous pull of the denture caused by mastication. 9,10

The mechanical strength of denture base can be improved in various ways, one of them is with the addition of glass fiber. ${ }^{11}$ Glass fiber is a fiber made of fine glass fibers containing silica dioxide (Si203). Strong covalent bonds and isotropic chemical structures in $\mathrm{Si203}$ lead to denser and stronger glass fibers so it can absorb loads received by heatpolymerized acrylic resins. In addition to Si203, boron trioxide also can improve the hydrolytic stability of glass fiber surface so that less water is absorbed and indirectly reduces the water absorption by the heat-polymerized acrylic resin denture base results in the improvement of impact and transverse strength.7,12

Goguta et al. (2006) reported that there was an increase in the impact strength of heat-polymerized acrylic resin with the addition of rod and woven glass fibers. ${ }^{13}$ Jaber (2011) reported that there was an increase in impact strength in acrylic resin group with the addition of chopped strands glass fiber with $6 \mathrm{~mm}$ size and $0.7 \%$ concentration. ${ }^{14}$ Sitorus and Dahar (2012) reported that the addition of chopped strands glass fiber with $4 \mathrm{~mm}, 6 \mathrm{~mm}$ and $8 \mathrm{~mm}$ size resulted in a significant increase in impact strength when compared to the heat-polymerized acrylic resin group without the addition of glass fiber. ${ }^{15}$

Nirwana (2005) stated that there was an increased in transverse strength significantly after the addition of glass fiber in hybrid acrylic resins. ${ }^{16}$ Vojvodic et al. (2008) stated that there was an increased in transverse strength in heatpolymerized acrylic resins (Meliodent) after addition of chopped strands and woven glass fibers (Kelteks). ${ }^{17}$ Unalan et al. (2010) in his research reported that the most significant increase in transverse strength occurred in heat-polymerized acrylic resins after the addition of chopped strands of glass fiber (Veltrotex). ${ }^{6}$ Watri (2010) examined the addition of chopped strand glass fiber with $1 \%, 1.5 \%$, and $2 \%$ concentration in heat-polymerized acrylic resins (QC 20), reported that there was an increased in impact strength and transverse strength with the addition of $1 \%$ glass fiber while the addition of $2 \%$ glass fiber can reduce the transverse strength of heat-polymerized denture base material. ${ }^{18}$

Lee (2001) reported that chopped strands of fibers $3 \mathrm{~mm}$ sized added to the heat-polymerized acrylic resins denture base more than $3 \%$ can significantly increase the modulus of elasticity. ${ }^{19}$ Keyf and Uzun (2001) reported that transverse strength, maximal deflection, and modulus of elasticity were increased in heat-polymerized acrylic resins added with $1 \%$ glass fiber. ${ }^{20}$ Orsi et al. (2012) found that the addition of $10 \%$ glass fiber can improve the modulus of elasticity. ${ }^{21}$ Polat et al. research (2013) also showed that the group with the addition of $3 \mathrm{~mm}$ glass fiber with $5 \%$ concentration in heatpolymerized acrylic resins increased the transverse strength and modulus of elasticity higher than the group without the addition of glass fiber. ${ }^{22}$ Marchi (2014) reported that the addition of $1 \%$ and $1.5 \%$ glass fibers in heat-polymerized denture base material will increase the transverse strength and modulus of elasticity. ${ }^{23}$
The purpose of this study was to determine the effect of the addition of E-glass fiber (Chopped strands $3 \mathrm{~mm}$ size) with $1 \%$ and $1.5 \%$ weight concentration on the heatpolymerized acrylic resin denture base material to impact strength, transverse strength, and modulus of elasticity, and the correlation between them.

\section{MATERIALS AND METHODS}

The study design was a true experimental study, namely posttest only control group design. Samples in this study were heat-polymerized acrylic resin material (QC-20, England) without E-glass fiber as control group and heat-polymerized acrylic resin with chopped strands $3 \mathrm{~mm}$ size E-glass fiber (Cam Elyaf San A.S., Kocaeli, Turkey) with $1 \%$ and $1.5 \%$ concentration. Samples for impact strength test were fabricated based on international organization for standardization (ISO 1567) with rectangular shape $50 \mathrm{~mm} x$ $6 \mathrm{~mm} \times 4 \mathrm{~mm}$ in size, ${ }^{24}$ while samples for transverse strength and modulus of elasticity test were fabricated in $65 \mathrm{~mm} \times 10$ $\mathrm{mm} \times 2.5 \mathrm{~mm}$ according to ADA Specification No. 12.25

The sample size of the study was determined according to Federer's formula, and according to the equation in this study each group were used 10 samples. Total samples for all test group were 90 samples. Test group were divided into 9 groups: control group impact strength test without addition of E-glass fiber (A), impact strength test group with addition $1 \%$ E-glass fiber (B), impact strength test group with addition $1.5 \%$ E-glass fiber $(\mathrm{C})$, control group transverse strength test without addition of E- glass fiber (D), transverse strength test group with addition 1\% E-glass fiber (E), transverse strength test group with addition $1.5 \%$ E-glass fiber $(\mathrm{F})$, control group modulus of elasticity test without addition of E-glass fiber (G), modulus of elasticity test group with addition $1 \%$ E-glass fiber $(\mathrm{H})$, modulus of elasticity test group with addition $1.5 \%$ E-glass fiber (I).

\section{Manufacturing the Mould}

Gypsum stone type III (Moldano, Heraeus Germany) was mixed with ratio $300 \mathrm{gr}$ powder and $90 \mathrm{ml}$ water, then the mixture was stirred with a vacuum mixer for 15 seconds then put into the lower cuvette and vibrated above the vibrator, after which the master model was planted in the lower cuvette with height as high as the dough casts surface. After the cast has hardened, the cuvette is opened, and the master model is removed from the cuvette.

\section{Manufacturing Heat-Polymerized Acrylic Resin Without E-glass Fiber Addition}

Control group samples (A, D, and G) were made using heatpolymerized acrylic resin (QC-20, England) by mixing 9gr polymer powder with $4.5 \mathrm{ml}$ monomer liquid (for three samples) and stirred slowly with cement spatula. After the dough reaches the dough stage, the dough is put into the mould pressed with a hydrolic press until 1000 Psi, then the upper cuvette is opened, and excessive acrylic is cleaned with Lecron. Then, the upper cuvette was closed and pressed with hydraulic press until 2200 Psi. 
Manufacturing Heat-Polymerized Acrylic Resin with EGlass Fiber Addition

Chopped strands $3 \mathrm{~mm}$ size of E-glass fiber (Cam Elyaf San A. S., Kocaeli, Turkey) was weighted as much as $1 \%$ (0.14gr for three samples) from heat-polymerized acrylic resin total weight for group B, E, and H. E-glass fiber was added to silane coupling agent liquid (Gammamethacryloxypropyltrimethoxysilane/MPS). E-glass fiber was then being dried at room temperature for 40 minutes and then placed in the oven for 1 hour at temperature $115^{\circ} \mathrm{C}$. Furthermore, E-glass fiber was placed in the polymer powder of heat-polymerized acrylic resin that already prepared in the acrylic pot. Then, the monomer liquid was added to ratio powder: liquid 9gr:4.5ml (For three samples) and stirred until homogenous.

After that, the acrylic was added in the mold with addition of $1.5 \%$ E-glass fiber for $\mathrm{C}, \mathrm{F}$, and I groups with the same procedure, by adding $0.2 \mathrm{gr}$ E-glass fiber (For three samples) in heat-polymerized acrylic resin.

\section{Curing Process}

Curing process was done with a water bath (Rost Frei, Germany) for 90 minutes with temperature $70^{\circ} \mathrm{C}$ (phase I), then curing temperature was raised to $100^{\circ} \mathrm{C}$ and kept constant for 30 minutes (phase II), after that the cuvette was cooled until room temperature.

\section{Finishing Process}

Excessive acrylic was removed and trimmed using a Fraser bur and the coarse part was smoothed with waterproof sandpaper no. 600, 800, 1000 and 1200 mounted to rotary grinder below running water each for 3 minutes at $500 \mathrm{rpm}$. Polishing was done with a Scotch-Brite brush mounted to polishing motor at speed $500 \mathrm{rpm}$ and using coarse pumice until shiny, then the sample was put in aquadest at $37^{\circ} \mathrm{C}$ for 48 hours in the incubator (ADA Specification No. 12). ${ }^{26}$

\section{Measurement of Impact Strength}

Measurement of impact strength was done using Charpy Impact Tester (Amslerotto Wolpert Werke GMBH, Germany). The sample was numbered on both ends, then placed in a horizontal position which rests on both ends of the tester, and the bending arm on the tester is locked, then the lock of the hammer arms is released so that it strikes the sample until it is broken (Fig. 1). The energy shown on the testers was read and recorded and then calculated the impact strength $\left(\mathrm{J} / \mathrm{mm}^{2}\right)$.

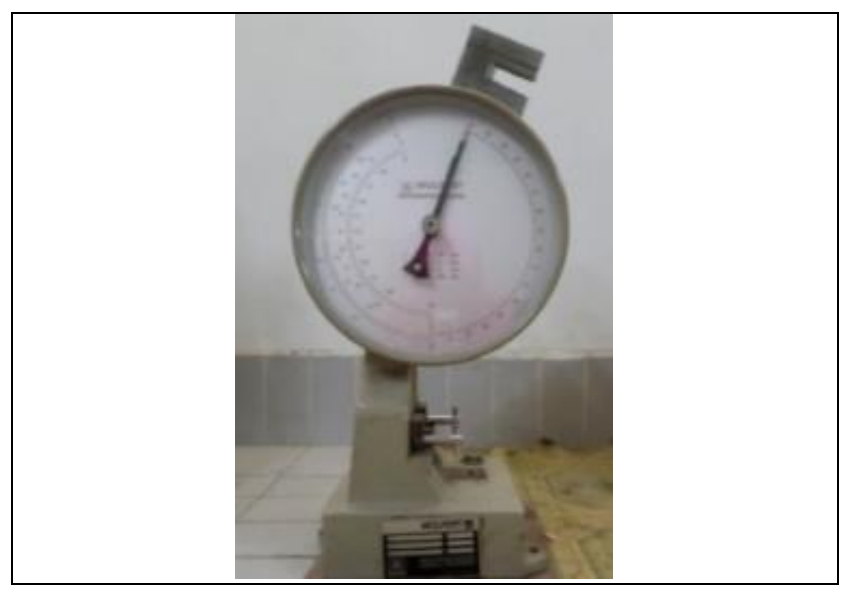

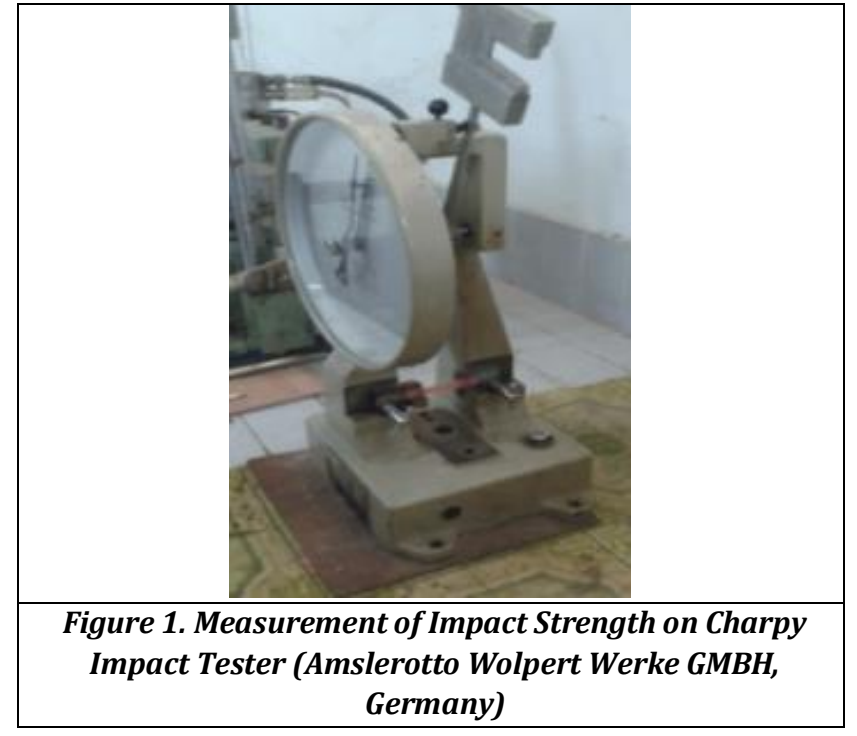

Measurement of Transverse Strength and Modulus of Elasticity

Measurement of transverse strength and modulus of elasticity was done by three-point bending test using Universal Testing Machine (Gotech AI-7000M Servo Control System Universal testing machine, Taiwan). The sample was numbered on both ends and the distance between its cross sections was calculated and the pedestal distance was adjusted, and the sample was placed on the test instrument in a horizontal position. The pressure pad was placed over the sample, a load was given in the center of the pedestal distance continuously until the maximum load and cracks arise (Fig. 2). The energy listed on the testers was read and recorded and then calculated transversal strength (MPa) and modulus of elasticity (MPa).

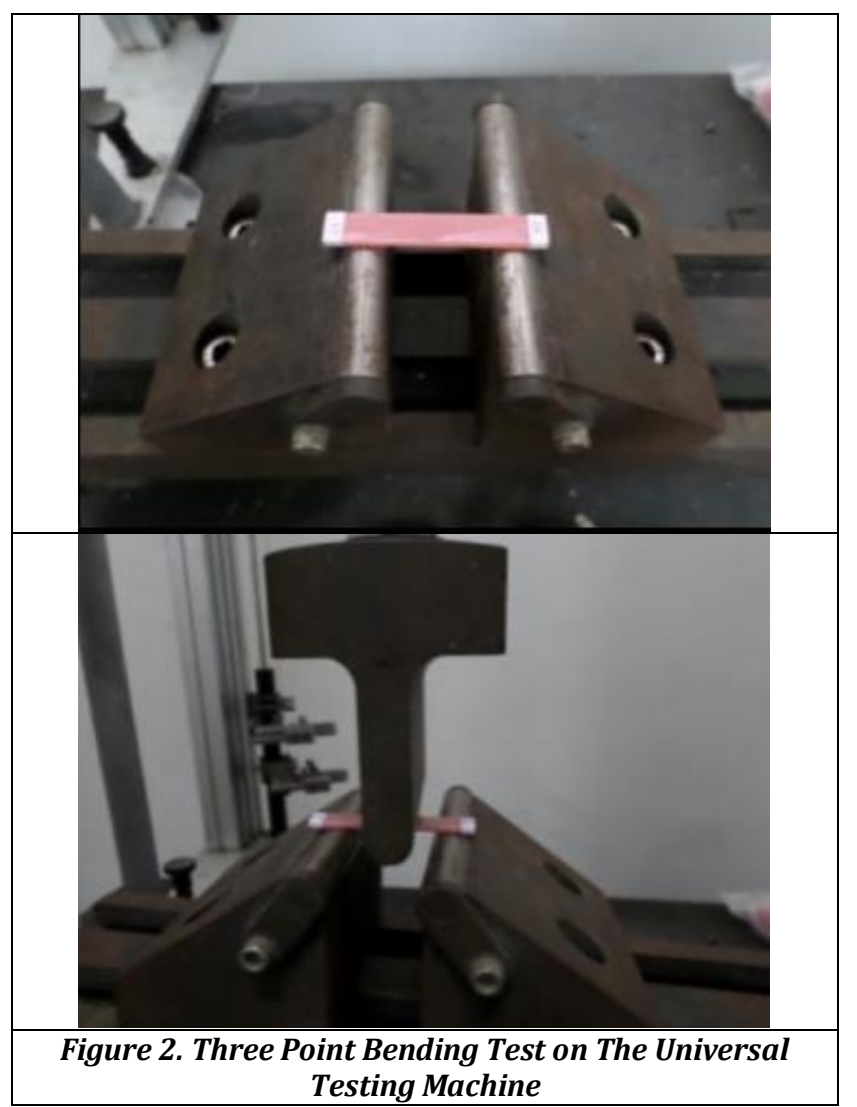




\section{Data Analysis}

After the measurements, the effect of E-glass Fiber addition to impact, transverse strength and modulus of elasticity of heatpolymerized acrylic resin were analysed with One-way ANOVA test. The comparison of effect among group without E-glass fiber, with addition $1 \%$ and $1.5 \%$ E-glass fiber was analysed with LSD test. Pearson Correlation test then performed to determine whether there was correlation between impact, transverse strength and modulus of elasticity.

\section{RESULTS}

\section{Effect of E-Glass Fiber Addition to Impact Strength}

The results showed an average value of impact strength were analysed with Univariate test. Mean and standard deviation of heat-polymerized acrylic resin without E-glass fiber was $5.689 \pm(1.597) \times 10^{-3} \mathrm{~J} / \mathrm{mm}^{2}$ while with addition of $1 \%$ E-glass fiber was $7.221 \pm(1.440) \times 10^{-3} \mathrm{~J} / \mathrm{mm}^{2}$ and with addition of $1.5 \%$ E-glass fiber was $8.691 \pm(1.171) \times 10^{-3} \mathrm{~J} / \mathrm{mm}^{2}$.

One-way ANOVA test results showed that there was a significant effect of the addition of $1 \%$ and $1.5 \%$ E-glass fiber on the impact strength of heat-polymerized acrylic resin $(\mathrm{p}=0.0001 ; \mathrm{p}<0.05)$. Based on LSD test results showed significant difference between heat-polymerized acrylic resin without and with addition $1 \%$ E-glass fiber $(\mathrm{p}=0.022$; $p<0.05)$ and with additional of $1.5 \%$ E-glass fiber $(p=0.0001$; $\mathrm{p}<0.05)$. Significant differences were also found between heat-polymerized acrylic resin with addition of $1 \%$ and $1.5 \%$ E-glass fiber (Table 1).

\begin{tabular}{|c|c|c|c|}
\hline \multirow[t]{2}{*}{ Group } & \multicolumn{2}{|c|}{$\begin{array}{c}\text { Impact Strength } \\
\left(\times 10^{-3} \mathrm{~J} / \mathrm{mm}^{2}\right)\end{array}$} & \multirow[t]{2}{*}{$\mathbf{p}$} \\
\hline & $\mathbf{n}$ & $\overline{\mathrm{x}} \pm \mathrm{SD}$ & \\
\hline Without E-glass fiber & 10 & $5.689 \pm(1.597)$ & \multirow{3}{*}{$0.0001^{*}$} \\
\hline E-glass fiber $1 \%$ & 10 & $7.221 \pm(1.440)$ & \\
\hline E-glass fiber $1.5 \%$ & 10 & $8.691 \pm(1.171)$ & \\
\hline \multicolumn{3}{|c|}{$\begin{array}{l}\text { The mean of impact strength is different between: } \\
\text { - Without E-glass fiber with E-glass fiber } 1 \% \\
\text { - Without E-glass fiber with E-glass fiber } 1.5 \% \\
\text { - E-glass fiber } 1 \% \text { with E-glass fiber } 1.5 \%\end{array}$} & $\begin{array}{c}0.022^{*} \\
0.0001^{*} \\
0.028^{*}\end{array}$ \\
\hline \multicolumn{4}{|c|}{$\begin{array}{c}\text { Table 1. Effect of Addition of 1\% and 1.5\% E-Glass Fiber On } \\
\text { the Impact Strength of Heat-Polymerized Acrylic Resin } \\
\text { Denture Base }\end{array}$} \\
\hline \multicolumn{4}{|c|}{ Note: *: Significant $(\mathrm{p}<0.05)$} \\
\hline
\end{tabular}

\section{Effect of E-glass Fiber Addition to Transverse Strength}

The results showed an average value of transverse strength were analysed with Univariate test. Mean and standard deviation of heat-polymerized acrylic resin without E-glass fiber was $92.788 \pm(13.855) \mathrm{MPa}$, with the addition of $1 \% \mathrm{E}$ glass fiber was $109.000 \pm(4.536) \mathrm{MPa}$, and with the addition 1.5\% E-glass fiber was $102.334 \pm(6.412) \mathrm{MPa}$.

One-way ANOVA test results showed that there was a significant effect of the addition of $1 \%$ and $1.5 \%$ E-glass fiber on the transverse strength of heat-polymerized acrylic resin denture base ( $p=0.002 ; p<0.05)$. Based on LSD test results, it showed a significant difference between heat-polymerized acrylic resin without and with addition of $1 \%$ E-glass fiber $(p=0.001 ; p<0.05)$. Significant differences were also found between heat-polymerized acrylic resin without and with addition of $1.5 \%$ E-glass fiber ( $\mathrm{p}=0.028 ; \mathrm{p}<0.05$ ) (Table 2).

\begin{tabular}{|c|c|c|c|}
\hline \multirow{2}{*}{ Group } & \multicolumn{2}{|c|}{ Transverse Strength (MPa) } & \multirow[b]{2}{*}{$\mathbf{p}$} \\
\hline & $\mathbf{n}$ & $\overline{\mathbf{x}} \pm \mathrm{SD}$ & \\
\hline Without E-Glass Fiber & 10 & $92.788 \pm(13.855)$ & \multirow{3}{*}{$0.002^{*}$} \\
\hline E-Glass Fiber 1\% & 10 & $109.000 \pm(4.536)$ & \\
\hline E-Glass Fiber 1.5\% & 10 & $102.334 \pm(6.412)$ & \\
\hline \multicolumn{3}{|c|}{$\begin{array}{l}\text { The Mean of Transverse Strength Is Different } \\
\text { Between: } \\
\text { - Without E-Glass Fiber with E-Glass Fiber 1\% } \\
\text { - Without E-Glass Fiber with E-Glass Fiber 1.5\% } \\
\text { - E-Glass Fiber 1\% With E-Glass Fiber 1.5\% }\end{array}$} & $\begin{array}{c}0.001^{*} \\
0.028^{*} \\
0.117\end{array}$ \\
\hline \multicolumn{4}{|c|}{$\begin{array}{c}\text { Table 2. Effect of the Addition of 1\% and 1.5\% E-Glass } \\
\text { Fiber on the Transverse Strength of Heat-Polymerized } \\
\text { Acrylic Resin Denture Base }\end{array}$} \\
\hline Note: & & cant $(\mathrm{p}<0.05)$ & \\
\hline
\end{tabular}

Effect of E-glass Fiber Addition to Modulus of Elasticity The results showed an average value of modulus of elasticity were analysed with Univariate test. Mean and standard deviation of heat-polymerized acrylic resin sample without Eglass fiber was $2788.843 \pm(460.376) \mathrm{MPa}$, with the addition of $1 \%$ E-glass fiber was $3221.867 \pm(234.206) \mathrm{MPa}$ and with the

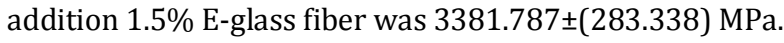

One-way ANOVA test results showed that there was a significant effect of the addition of $1 \%$ and $1.5 \%$ E-glass fiber on the modulus of elasticity of heat-polymerized acrylic resin denture base $(\mathrm{p}=0.002 ; \mathrm{p}<0.05)$. Based on LSD test results, it showed a significant difference between heat-polymerized acrylic resin without and with addition of $1 \%$ E-glass fiber $(\mathrm{p}=0.008 ; \mathrm{p}<0.05)$. Significant differences were also found between heat-polymerized acrylic resin without and with addition of $1.5 \%$ E-glass fiber ( $p=0.001 ; \mathrm{p}<0.05$ ) (Table 3).

\begin{tabular}{|c|c|c|c|}
\hline \multirow{2}{*}{ Group } & Modulus of Elasticity (MPa) & \multirow{2}{*}{ p } \\
\cline { 2 - 3 } & $\mathbf{n}$ & $\overline{\mathbf{x}} \pm$ SD & \\
\hline Without E-glass fiber & 10 & $2788.843 \pm(460.376)$ & \\
\hline E-glass fiber 1\% & 10 & $3221.867 \pm(234.206)$ & \multirow{2}{*}{$0.002^{*}$} \\
\hline E-glass fiber 1.5\% & 10 & $3381.787 \pm(283.338)$ & \\
\hline \multicolumn{3}{|c|}{ The mean of Modulus of Elasticity is different } & \multirow{2}{*}{ between: } \\
- Without E-glass fiber with E-glass fiber 1\% & $0.008^{*}$ \\
- Without E-glass fiber with E-glass fiber 1.5\% & 0.302 \\
- E-glass fiber 1\% with E-glass fiber 1.5\% & \\
\hline Table 3. Effect of the Addition of 1\% and 1.5\% E-glass \\
Fiber On the Modulus of Elasticity of Heat-Polymerized \\
Acrylic Resin Denture Base \\
\hline \multicolumn{4}{|c|}{ Note: *: Significant (p<0.05) } \\
\hline
\end{tabular}

\section{Scanning Electron Microscope (SEM) Analysis}

The SEM photographs on fracture surface of impact strength samples without E-glass fiber presence of voids and surface texture of compression side is rougher than on tension side. In sample with the addition of $1 \%$ and $1.5 \%$ E-glass fiber showed voids or porosity on resin matrix, inadequate E-glass fiber impregnation and un-equally distribution of E-glass fibers to resin matrix. The surface texture of the compression side of the resin matrix is rougher while on the tension side is smoother (Fig. 3). 


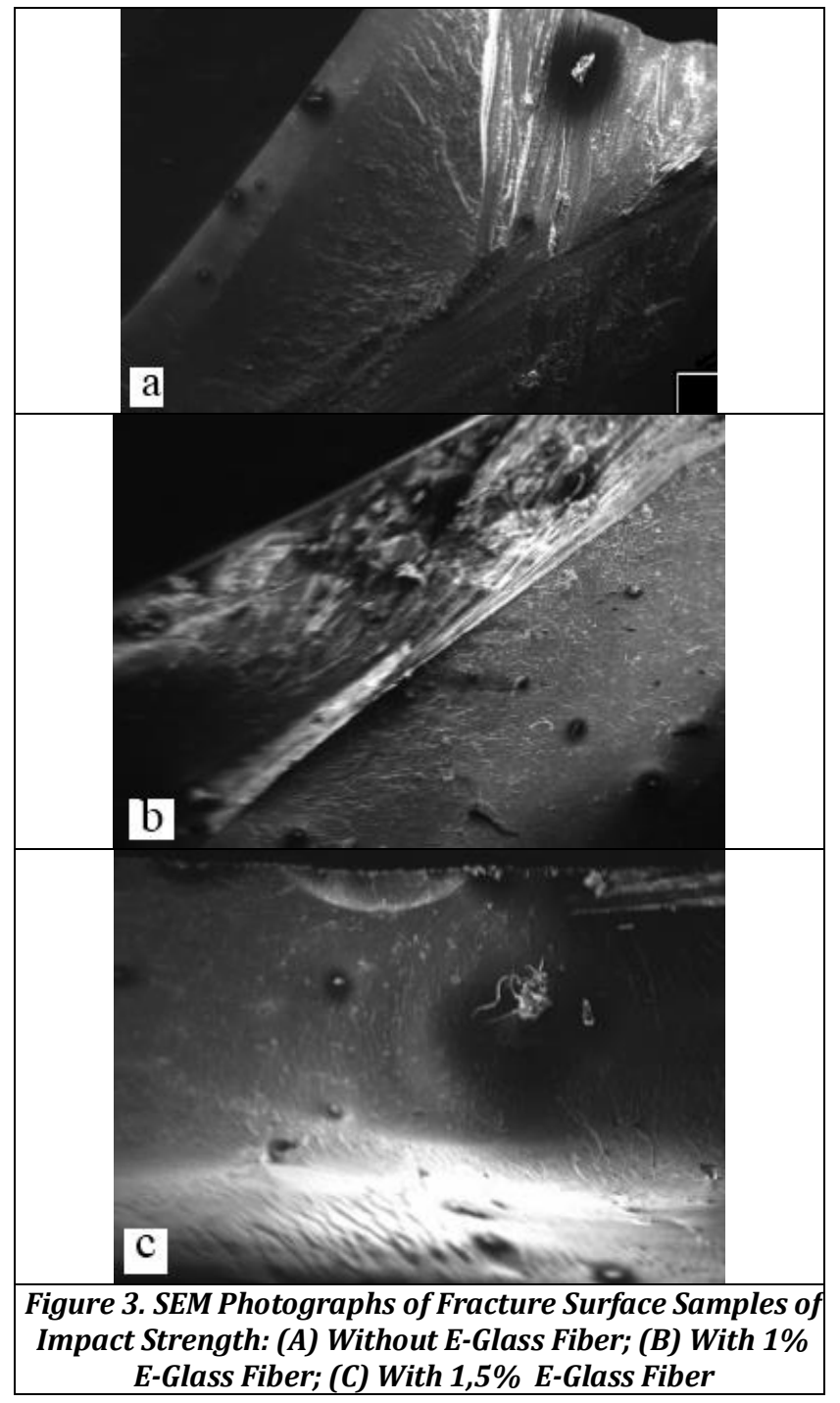

The SEM photographs on fracture surface of transverse strength and modulus of elasticity samples without E-glass fiber presence of voids and surface texture of compression side is rougher than on tension side. In sample with the addition of $1 \%$ and $1.5 \%$ E-glass fibers showed that the acrylic resin matrix is more dense but there is still a void or porosity on resin matrix surface, the impregnation of E-glass fiber with resin matrix is seen to be sufficient adequate but the E-glass fiber distribution is not clearly visible on the SEM photographs. The surface texture of the compression side of the resin matrix is rougher while on the tension side is smoother (Fig. 4).

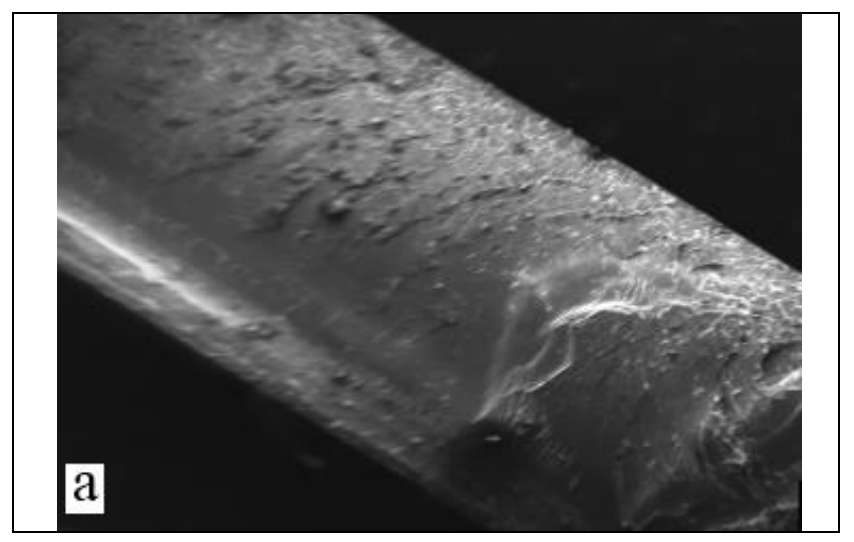

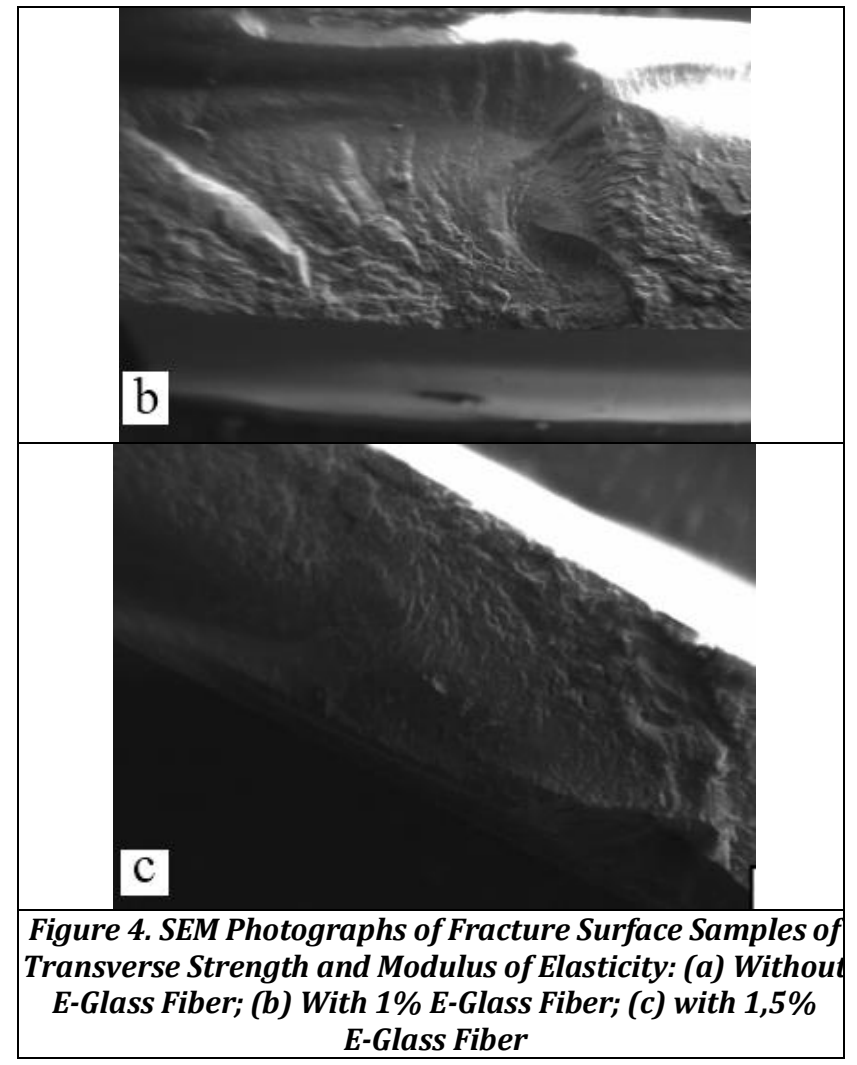

Correlation between Impact Strength, Transverse Strength and Modulus of Elasticity of Heat-polymerized Acrylic Resin with the Addition of $1 \%$ and $1.5 \%$ E-glass Fiber

Pearson correlation test results showed there was no correlation between impact strength with transverse strength ( $\mathrm{r}=0.311$ and $\mathrm{p}=0.094)$, there was no correlation between impact strength and modulus of elasticity( $\mathrm{r}=0.284$ and $\mathrm{p}=0.128$ ), and there was no correlation between transverse strength and modulus of elasticity $(\mathrm{r}=-0.044$ and $\mathrm{p}=0.816$ ) (Table 4).

\begin{tabular}{|c|c|c|c|}
\hline Correlation & $\mathbf{n}$ & $\mathbf{r}$ & $\mathbf{p}$ \\
\hline $\begin{array}{c}\text { Impact Strength with Transverse } \\
\text { Strength }\end{array}$ & 30 & 0.311 & 0.094 \\
\hline $\begin{array}{c}\text { Impact Strength with Modulus of } \\
\text { Elasticity }\end{array}$ & 30 & 0.284 & 0.128 \\
\hline $\begin{array}{c}\text { Transverse Strength with Modulus of } \\
\text { Elasticity }\end{array}$ & 30 & -0.044 & 0.816 \\
\hline
\end{tabular}

Table 4. Correlation Between Impact Strength, Transverse Strength and Modulus of Elasticity of Heat-Polymerized Acrylic Resin with the Addition of 1\% and 1.5\% E-Glass Fiber

Note: *: Significant $(\mathrm{p}<0.05)$

\section{DISCUSSION}

Impact strength value in this study varied on each sample, this was due to several factors that cannot be controlled during the research such as residual monomer, manual stirring technique in which the stirring speed cannot fully controlled and the internal porosity which cannot be seen.2,3 Vojvodic (2008) in his study using heat-polymerized acrylic resin (meliodent) added with E-glass unidirectional fiber (Kelteks) and compared with the high impact strength of resin stated that manual stirring technique can caused inhomogeneous mixture between E-glass fiber and polymer 
and trapping the air within the heat-polymerized acrylic resin matrix and caused porosities that affects the impact strength of the heat-polymerized acrylic resin. ${ }^{17}$

The results in this study was in accordance with previous study by Stipho (1998) and stated that the addition of $1 \%$ glass fiber on heat-polymerized acrylic resin denture base can increased the transverse strength, however, if the concentration of glass fiber was more than $1 \%$, it can cause a decreased in transverse strength. According to Stipho, the addition of more than $1 \%$ glass fiber can caused coagulation of glass fiber so that the mixture between polymer, monomer, and glass fiber becomes inhomogenous. ${ }^{27}$ Yondem (2011) in his research reported that there was an increased in transverse strength in heat-polymerized acrylic resin added with glass fiber. This was due to the adhesion between glass fiber and acrylic resin polymer matrix so that the load can be distributed evenly. Good adhesion between glass fiber can also be caused by surface treatment of glass fiber before stirring the polymer and monomer of heat-polymerized acrylic resin using silane coupling agent. 10

Results in this study showed that there was an effect of $1 \%$ and $1.5 \%$ E-glass fiber addition on the transverse strength of heat-polymerized acrylic resin denture base due to a significant result $\mathrm{p}=0.002(\mathrm{p}<0.05)$ obtained in this research. This result was in accordance with Tacir (2006) research stated that there was a significant effect of small piece E-glass fiber addition on transverse strength of heatpolymerized acrylic resin. ${ }^{28}$ An increased in transverse strength in acrylic resin group added with $1 \%$ and $1.5 \% \mathrm{E}$ glass fiber may be due to the main composition of glass fiber consists of silica dioxide $\left(\mathrm{SiO}_{2}\right)$ that was rigid and high value of strength, so that the glass fiber structure becomes more dense and strong and able to absorbs all loads received by heat-polymerized acrylic resin. When the load is successfully transferred from the heat-polymerized acrylic resin to the glass fiber, it will increase the transverse strength of the heatpolymerized acrylic resin denture base. ${ }^{7}$

Result showed that there was an effect of the addition of $1 \%$ and $1.5 \%$ E-glass fiber on modulus of elasticity of heatpolymerized acrylic resin $(\mathrm{p}=0.002 ; \mathrm{p}<0.05)$. Orsi et al. (2012) reported that modulus of elasticity value significantly higher in groups added with glass fiber than control group. Glass fiber increased the rigidness of the polymer used in this research. Heat-polymerized acrylic resin strongly affects the conversion degree of polymer matrix, where the higher the conversion degree, the more rigid the material. ${ }^{21}$

Larson et al. and Inamura et al. in their research reported that there was an increased in modulus of elasticity with the addition of glass fiber in heat-polymerized acrylic resin. ${ }^{29}$ Modulus of elasticity is an important mechanical property in receiving mastication loads. To reduce the polymerization shrinkage, the polymer component from denture base material must be modified using materials that were rigid or higher modulus of elasticity. ${ }^{22}$ Glass fiber has a rigid properties or higher modulus of elasticity that can affects the flexibility of denture base, so that the loads received from denture base did not cause deformation. ${ }^{30}$

Voids or micro porosity that was found on SEM photographs in this study is probably caused by shrinkage polymerization due to residual monomers. The rougher surface texture of the compression side compared to the tension side was probably due to the force applied directly to the compression side, so that a direct impact on the resin matrix surface resulting in more severe damage to the compression side. In SEM photographs, there was also found not equally distributed of E-glass fiber, this is probably caused by the spread of E-glass fiber during compression moulding of heat-polymerized acrylic resin so that the concentration of E-glass fiber in each sample was different.

In this study, there were no correlation between impact strength, transverse strength, and modulus of elasticity $(p>0.05)$. Lee et al. (2012) stated that results of impact strength was often compared with transverse and fracture resistance in previous study, however, it was found that there was a weak correlation between impact strength and transverse strength or modulus of elasticity. Zappini et al. reported that impact strength only showed a moderate correlation with fracture resistence. ${ }^{31}$

\section{CONCLUSION}

Addition of $1 \%$ and $1.5 \%$ E-glass fiber in heat-polymerized acrylic resin denture base can improve the mechanical properties (impact strength, transverse strength, and modulus of elasticity) of heat-polymerized acrylic resin denture base in cases that are susceptible to fracture and the addition of $1 \%$ E-glass fiber can increase the impact strength, transverse strength, and modulus of elasticity. There was no correlation between impact strength and transverse strength $(\mathrm{r}=0.311$ and $\mathrm{p}=0.094)$; impact strength and modulus of elasticity $(\mathrm{r}=0.284$ and $\mathrm{p}=0.128)$; transverse strength and modulus of elasticity ( $r=-0.044$ and $p=0.816)$ of heatpolymerized acrylic resin denture base after the addition of $1 \%$ and $1.5 \%$ E-glass fibers.

\section{REFERENCES}

[1] McCabe JF, Walls AWG. Applied dental materials. 9th edn. London: Blackwell Publishing Ltd., 2008: p. 11023.

[2] Powers JM, Sakaguchi RL. Craig's restorative dental materials. 12 $2^{\text {th }}$ edn. Mosby Elsevier 2006.

[3] Alla RK, Sajjan S, Alluri VR, et al. Influence of fiber reinforcement on the properties of denture base resins. Journal of Biomaterials and Nanobiotechnology 2013;4:91-7.

[4] Narva KK, Lassila LV, Vallittu PK. The static strength and modulus of fibre reinforced denture base polymer. Dent Mater 2005;21(5):421-8.

[5] Raszewski Z, Nowakowska D. Mechanical properties of hot curing acrylic resin after reinforced with different kinds of fibres. International Journal of Biomedical Materials Research 2013;1(1):9-13.

[6] Unalan F, Dikbas I, Gurbuz 0. Transverse strength of polymethylmethacrylate reinforced with different forms and concentrations of E-glass fibres. OHDMBSC 2010;9(3):144-7.

[7] Mowade TK, Dange SP, Thakre MB, et al. Effect of fiber reinforcement on impact strength of heat polymerized polymethyl methacrylate denture base resin: in vitro study and SEM analysis. J Adv Prosthodont 2012;4(1):30-6. 
[8] Yu SH, Ahn DH, Park JS, et al. Comparison of denture base resin reinforced with polyaromatic polyamide fibres of different orientations. Dental Materials Journal 2013;32(2):332-40.

[9] Prasad AH, Kalavathy, Mohammed HS. Effect of glass fibre and silane treated glass fibre reinforcement on impact strength of maxillary complete denture. Annals and Essences of Dentistry 2011;4(3):7-12.

[10] Yöndem I, Yücel M, Aykent F, et al. Flexural strength of denture base resin reinforced with different fibers. SÜ Dişhek Fak Derg 2011;20:15-20.

[11] Vojdani M, Khaledi AAR. Transverse strength of reinforced denture base resin with metal wire and eglass fibres. J Dent, Tehran University of Med Sci 2006;3(4):167-72.

[12] Monaco C. Clinical and scientific aspect of inlay fixed partial denture. Thesis, Italia, University of Siena. 2005: p. 1-39.

[13] Goguta L, Marsavina L, Bratu D, et al. Impact strength of acrylic heat curing denture base resin reinforced with e-glass fibres. TMJ 2006;56(1):88-92.

[14] Jaber MA. Effect of metal wire and glass fibers on the impact strength of acrylic denture-base resin. Iraqi National Journal of Nursing Specialities 2011;24(2):26-32.

[15] Sitorus Z, Dahar E. Perbaikan sifat fisis dan mekanis resin akrilik polimerisasi panas dengan penambahan serat kaca. Dentika Dental Journal 2012;17(1):24-9.

[16] Nirwana I. Kekuatan transversal resin akrilik hybrid setelah penambahan glass fiber dengan metode berbeda. (The transverse strength of the hybrid acrylic resin after glass fibre reinforcement with different method). Majalah Kedokteran Gigi (Dent J) 2005;38(1):16-9.

[17] Vojvodic D, Matejicek F, Schauperl Z, et al. Flexural strength of e-glass fibre reinforced dental polymer and dental high impact strength resin. Strojarstvo 2008;50(4):221-30.

[18] Watri D. Pengaruh penambahan serat kaca pada bahan basis gigitiruan resin akrilik polimerisasi panas terhadap kekuatan impak dan transversal. Skripsi Medan Universitas Sumatera Utara 2010: p. 42-53.

[19] Lee SI, Kim CW, Kim YS. Strength of chopped glass fiber on the strength of heat-cured PMMA resin. J Korean Acad Prosthodont 2001;39(6)589-98.
[20] Uzun G, Keyf F. The effect of woven, chopped and longitudinal glass fibres reinforcement on the transverse strength of a repair resin. J of Biomaterial Application 2001;15(4):351-8.

[21] Orsi IA, Soares RG, Villabona CA, et al. Evaluation of the flexural strengh and elastic modulus of resins used for temporary restorations reinforced with particulate glass fibre. Gerodontology 2012;29(2):e63-e8.

[22] Polat TN, Dogan DO, Topcuoglu S, et al. Effect of different glass fibers on the transverse strength and elastic modulus of repairing acrylic resin. Cumhuriyet Dent J 2013;16(3):1-9.

[23] Mareti D. Pengaruh penambahan serat kaca terhadap kekuatan transversal dan modulus elastisitas bahan basis gigitiruan resin akrilik polimerasasi panas. Skripsi, Medan, Universitas Sumatera Utara, 2014: p. 7-56.

[24] Memon MS, Yunus N, Razak AA. Some mechanical properties of a highly cross-linked, microwave polymerized, injection-molded denture base polymer. Int J Prosthodont 2001;14(3):214-8.

[25] Jain T, Yadav NS, Pandita S, et al. A comparative evaluation of flexural strength of commercially available acrylic and modified polymethylmethacrylate: an invitro study. J Contemp Dent Pract 2013;14(1):80-3.

[26] Khalaf HAR. Effect of Siwak on certain mechanical properties of acrylic resin. J Oral Research 2013;1(1):39-49.

[27] Stipho HD. Repair of acrylic resin denture base reinforced with glass fibre. J Prosthet Dent 1998;80(5):546-50.

[28] Tacir IH, Kama JD, Zortuk M, et al. Flexural properties of glass fibre reinforced acrylic resin polymers. J Aust Dent 2006;51(1):52-6.

[29] Vallittu PK, Bodont DT, Lassila VP, et al. Acrylic resinfibre composite-part I: the effect of fiber concentration on fracture resistance. J Prosthet Dent 1994;71(6):607-12.

[30] Tandon R, Gupt S, Agarwal SK. Denture base materials: from past to future. Indian Journal of Dental Sciences 2010;2(2):33-9.

[31] Lee HH, Lee CJ, Asaoka K. Correlation in the mechanical properties of acrylic denture base resins. Dent Mater J 2012;31(1):157-64. 